\title{
Economic Development: Threats and Opportunities
}

\section{Vincenzo Ruggiero}

Department of Criminology and Sociology, Middlesex University Hendon Campus, London, UK.

Email: V.Ruggiero@mdx.ac.uk

Received May $14^{\text {th }}$, 2012; revised June $18^{\text {th }}, 2012$; accepted June $28^{\text {th }}, 2012$

\begin{abstract}
Economic initiative, by definition, is a human and social effort devoted to the collective wellbeing. However, economic development in general, along with more or less measurable benefits, may cause harm to people and the environment. This aspect tends to be obscured by advocates of the currently predominant philosophy (or ideology) known as neo-liberalism. This paper sets off with a critical analysis of the axioms of neo-liberalism focusing on the variable risk and on the harm provoked by economic development on the environment. Straddling legality and illegality, harmful economic conduct is then equated to a specific form of white collar crime, while an attempt is made to trace in the history of economic thought itself the embryo of a destructive rationale. After considering how harm to individuals and the environment is hidden through ideological strategies, the paper looks at some refreshing proposals to turn the threats of economic development into human opportunities.
\end{abstract}

Keywords: Neo-Liberalism; Risk; Law; Economy; Valueless Lives

\section{Axioms and Risk}

As an ideology, neo-liberalism serves to legitimise economic conduct by conferring on it the character of inevitability, of a divine project aimed at the happiness of all. To hamper such project is tantamount to sacrilege, and governments still convinced that their role consists in civilizing the economy and the human interactions this entails had better adhere to the new ideology lest they are doomed. The political sphere is required to forge its own philosophy through the concepts and axioms prompted by the economy, making society suitable to it, rather than the other way round. The marriage between economics and politics is so harmonious that representatives of the two realms swap functions and arenas, and have become by now perfectly interchangeable [1]. Entrepreneurs become politicians while the latter, after their mandate expires, find comfortable positions within business boards of directors.

Neo-liberal ideology posits that a 2 - 3 point growth per year is indispensable, even for societies which have reached a satisfying degree of wellbeing, to continue to enjoy such wellbeing. A corresponding increase in consumptions, inevitably, has to be stimulated. Whether permanent growth manifests dysfunctional aspects, for humans and their environment, should not concern us, because, so go other axioms: a) markets are perfectly able to self-regulate; b) capital flows without hesitation where its utility is maximum; c) risks are always calculable [2].
As for the enormous mismatch between technological and economic potentials and the actual life conditions of the population of the earth, the "trickle down" principle will soon display its healing capacity. Little attention is given to the growing signs that the use of natural resources implied by an economic model based on infinite development is unsustainable, and that the time left to change it is shrinking dramatically.

The ecological footprint of the planet in 2008 was close to 1.3, namely the earth was using all its own natural resources plus a third of those of another planet... If this tendency continues unaltered, the estimate is that in 2050 the earth will need an entire second planet in order to satisfy its use of natural resources, including the capacity to absorb or recycle the waste thus produced... If developing countries came close to the levels of consumption of the EU, 2.1 planets would be necessary. If the entire world reached the levels of consumption of the US, the earth would need the resources of four more planets [2].

Each society identifies a "threshold of catastrophe" which derives from its perception of the utility brought by risky behaviour. Where this threshold is located is highly controversial. Societies and economies of subsistence, for example, may be highly opposed to risky decisions because they are constantly threatened by the loss of crops, the uncertainty of their productive system, and ultimately by famine. Similarly, in monetary economies, entrepreneurs who hold limited finances may be deemed 
less prepared to run risks than their colleagues who own more funds. On the other hand, one may also suggest that lack and uncertainty may lead to riskier behaviour as a way of "gambling" one's way towards abundance and a secure future. In this sense, it is those endowed with fewer resources that might be prepared to run higher risks. In brief, the perception of risk and catastrophe is not only based on scientifically shared calculus, but is also heavily dependent on subjectivity.

In the seventeenth century risk was associated with gambling, which entails simultaneous possibilities of loss and gains. Slowly, gains vanished from the equation, while the negative outcomes of gambling were linked to taboos and sins. The major moments of choice were signposted with danger. Later, the public politicised the subject, while scientists pretended to be neutral [3]. This politicisation of the subject matter occurs because society no longer runs risks in pursuit of what is necessary, but of what is superfluous [4]. In this way, the identification of a threshold of catastrophe becomes increasingly dependent on who is likely to earn advantages from risky behaviour. Those who feel that risk, or gambling, will bring advantages to others than themselves, will move the threshold of catastrophe accordingly. In sum, the very perception of catastrophe and risk varies according to the position one occupies in "gambling": some individuals may make decisions while others may just suffer the outcomes of those decisions [5].

We spend money we don't have, on things we don't need, to make impressions that don't last, on people who don't care. Because we do not run risks in the pursuit of what is necessary, but of what is superfluous, neo-liberalism needs to turn the superfluous into a natural product of human activity or even into an element of human organic reproduction. Hence its need to imitate the natural sciences, biologists, physicists, mathematicians and other scientists have been called upon to make economic theories more "realistic and effective", namely to inoculate doses of dogma into them. As Gallino [2, pp. 94-95] has noted, the major opus of economics produced in the 20th century, the General Theory of Keynes (1936), out of a total 400 pages included, mainly in the appendix, three or four simple equations. In 1950 only 2 - 3 per cent of the articles published by the influential American Economic Review contained mathematic formulas, which normally were not at all sophisticated. In 1980 the papers with mathematical calculations were 44 per cent and formulas had become much more complex. Currently the percentage is close to 90 per cent. The only "real" science within the human sciences, neo-liberal economics dominates in university courses, in the specialist literature, and in most schools of management and business. It is the core religion of business administrators, large enterprises, financial institutions, ministries of the economy, central banks, international organisations, the World Bank, the World Monetary Fund and the European Commission.

The economy is seen as a physical system, implying flows of goods, information and energy, so that it might be useful to model the economy as a system, like physics does. However, while economic theory uses the concept of equilibrium, the same concept used by physics cannot be applied to the economy, because this is an open system and equilibrium refers to closed systems [2, p. 92].

Neo-liberalism does not observe and describe the economic reality, it creates this reality. It also produces a new conceptualisation of risk: from risk as uncertainty for enterprise to risk as uncertainty for society at large. This shift contradicts one of the very axioms of free markets, namely that the full costs of a transaction must be borne by the involved parties. Many economic activeties and transactions, however, exact a significant price on humans and ecosystems, although economists label such price with the reassuring euphemism "externalities" [6]. In brief, neo-liberalism regards environmental harm as an accidental, unintentional, externality.

\section{Law and Economy}

The analysis of harm-producing economic development bears close resemblance with that of white collar crime, as both are situated on what scholars addressing the latter describe as the legal-illegal continuum. The notion that there is continuity between legality and illegality is crucial for an understanding of white collar, corporate, state crime, and of the crimes of the powerful in general. This notion may be fruitfully utilised when harmful economic conduct is analysed, as this can result from illicit as well as totally lawful initiative [7]. The study of harmful economic conduct, in other words, encounters the same theoretical predicament experienced by students of the crimes of the powerful and campaigners mobilising against them. As Sutherland realized, research on the crimes of the powerful is difficult without a willingness to expand one's sample well beyond the legal definitions of crime. Global warming, for instance, may be likened to sate-corporate crime [8], although in general one should specify that the harm caused by economic initiative is the outcome of a series of interlaced conducts that are "bad" in themselves, on the one hand, and conducts that are "bad" because they are prohibited by law, on the other. In sum, harm-producing development contains at the same time mala in se and mala prohibita.

In his analysis of the relationship between the law and the economy, Max Weber [9] notes that there are limits to the success of legal coercion in the economic sphere. Such limits are dependent on the strength of the actors involved, respectively pursuing their material interests and promoting conformity to the law. "The inclination to 
forego economic opportunity simply in order to act legally is obviously slight, unless circumvention of the formal law is strongly disapproved by a powerful convention" [9, p. 335]. In the economic sphere, on the other hand, "it is often not difficult to disguise the circumvention of the law", as economic action creates its own legitimacy in the material as well as the legal realm. Inadvertently or not, Weber's remarks fall into the arena of the crimes committed by powerful individuals and groups, where offenders possess an exorbitantly exceeding amount of material and symbolic resources when compared to those possessed by their victims. The designation of harmful economic conduct as crime is controversial and highly problematic, due to the higher capacity on the part of powerful economic actors to control the effects of their actions and to conceal (or negotiate) their criminal nature. Such actors enjoy a "control surplus", namely an excess of control exercised on others relative to the control they are subjected to by others [10]. Their conduct is "foundational", in the sense that it takes shape in a grey area in which behaviour awaits the outcome of the criminalisation-decriminalisation conflict, as it may be subject to regulation or become accepted routine. Some economic initiatives are enacted within vaguely regulated arenas and while presenting themselves as acceptable conduct end up creating a precedent. Other initiatives implicitly invoke legal pragmatism, challenging legal reasoning and advocating departure from precedents [11]. Economic action invoking legal pragmatism is foundational in nature, as it is inspired by an "experimental" logic and driven by a consequentialist philosophy. Powerful actors so driven adopt certain practices with the awareness that they may be unorthodox, but with an eye to the social and institutional reactions that might ensue. It is the intensity of such responses which will determine whether such practices become part of a "viable" routine or are to be carefully avoided. Some economic initiatives, in sum, possess a "founding force", namely they are capable of transforming the previous jurisprudence and establishing new laws and new types of legitimacy [12]. Foundational economic action restructures the legal and the political spheres while playing a legislative role.

A variety of foundational power crimes fall in the economic domain and pertain, specifically, to the environment, where forcing the rules often results in new rules being devised, in a race which sees the law chasing the economy, rather than vice-versa.

\section{Destroying through "Science"}

At one extreme of the legal-illegal continuum we find conducts which are detrimental to the environment but enjoy the "scientific" sanction of economic thought. These are "crimes of the economy" and deserve more attention than they are usually given by criminologists, some of whom still believe, by contrast, that economic development is in itself a key tool of crime prevention. Economists have often paid visits to the field of criminology, examining the rational logic of offending. It is time to return the visit, in order to ascertain whether the traces of some familiar criminological concepts can be found there [13]. But, first, let us outline some interesting recent developments in criminology.

Green criminologists analysing global environmental harm straddle legal-procedural approaches, which define harm as the outcome of illegal practices, and ecological approaches, which contemplate environmental harm more broadly, "by invoking notions of environmental morality, environmental ethics, and animal, ecological, or human rights” [14, p. 161]. In doing so, they are faced with the dilemma known in ecological theory and practice as the distinction between "shallow" and "deep" ecologism. The former appears to believe that the technology which is destroying the environment may also rescue it: a managerial approach to environmental problems will be sufficient to solve problems, without fundamental changes in present values or patterns of production and consumption. Deep ecology, by contrast, embraces a holistic outlook, whereby humans are interconnected with each other and are constantly in relationship with everything around them - they are part of the flow of energy, the web of life. Radical changes in production and consumption patterns, but also in the fundamental principles and values expressed by the undeservedly respected "science" of economics, are necessary.

Is the environment a public good? "Yes", if we, in abstract terms, assimilate it to other non-rival, non-excludable goods, in the sense that one person's enjoyment of the environment does not exclude its enjoyment by others, and in the sense that the good environment is provided to one and all at the same time. However, the answer is "No" if we believe that goods and resources belong to those who turn them into wealth. Economic thought starts its "scientific" arguments from the latter assumption, and in the texts of the founding fathers of economic liberalism this assumption takes the form of rationalisation for the plunder and destruction of colonial regions. John Locke [15], for example, laid the philosophical groundwork for human freedom in all its dimensions: free enterprise, free trade, free competition, and the freedom to invest. Freedom to destroy, in his thought, takes the form of exploitation of the earth, which cannot be left there as an object of contemplation, but has to be turned into property as the result of improvement and work. By leaving fruits to rot and venison to putrefy, and for that matter by leaving the earth untouched, we offend the common law of nature. 
Thrift, work and perseverance may replace inherited rights to property, but is there a limit in hoarding up more than one can make use of? By the same token, is there a limit beyond which the exploitation of the earth constitutes a threat to the planet? John Locke believes that the "bounds of just property" have been removed with the invention of money, which makes economic initiative boundless and infinite, money being "some lasting thing that men might keep without spoiling” [15, p. 140]. Natural resources, in this view, must be turned into monetary value, because if left idle they will dissipate. Colonies and their inhabitants were a substantial part of the natural resources this type of reasoning referred to.

The entire earth, today, can be likened to the resources of the old colonies, including slaves, all given to us not for the mere purpose of contemplation or for leading a good life, but with the implicit mandate to use and exploit them. The environment, therefore, is not a common good, but an arena where the capacity and ingenuity of humans is constantly tested, and such capacity and ingenuity appear to be the only limit to initiative and development. The ultimate resource, in brief, is the human mind, and throughout history human genius always wins out against natural resource restraints.

Physiocrats such as Quesnay [16, p. 15] urged that "the land employed in the cultivation of corn be brought together, as far as possible, into large farms worked by rich husbandmen; for in large agricultural enterprises there is less expenditure required for the upkeep and repair of buildings, and proportionally much less cost and much more net product than in small ones". Small farms, instead, "employ uselessly, and at the expense of the revenue of the land, a greater number of the families of farmers, the extent of whose activities and means hardly puts them in a position to carry on wealthy cultivation”. Wealthy cultivation, to be sure, consists of intensive and limitless exploitation of the soil, accompanied by enclosures and privatisation of the land, and the boundless use of resources. Growth is a permanent concern, as revenues cannot remain inert, "to the detriment of the reproduction of the revenues and the well-being of the people" [16, p. 5]. Similarly, capital should not be taxed, otherwise growth is inhibited and development hampered.

Physiocracy contributed to the description of the material sphere of society, where wealth is created and consumed, as a living organism, with its own blood circulation, its veins and arteries. Quesnay's economic tables offered an organic representation of economic life as an autonomous system, thus paving the way for the definitive divorce between economics and ethics. From then on, one sphere of human action increasingly distanced itself from other common values orienting social interaction: economics could no longer abide by the useless and damageing principles governing the socialisation of groups and individuals. Economics became a science.

Adam Smith granted the final seal to this science, positing the existence of a universal, timeless individual engaged in the constant pursuit of material interests, thus turning the immorality of accumulation into an instincttive, biological necessity. Infinite growth becomes a spontaneous mechanism involving productive agents who transform resources into commodities and wealth: such agents are the only representative of civility in that they provide the necessary livelihood for all. Glorifying producers, in Adam Smith, goes hand in hand with ridiculing those whose activity does not yield quantifiable value or net profit, such as domestic servants, politicians, soldiers, judges, artists, teachers and clergy. Lawyers, men of letters and musicians are equated to opera singers, opera dancers and buffoons [17]. Such unproductive individuals do not "work" because they do not transform anything: their performance perishes as soon as it is delivered, leaving the surrounding environment unchanged. Homo oeconomicus opposes sterility and is urged into developing innovative ideas leading to the relentless conquest and re-shaping of the environment, in a process that coincides with innate desire and the search for human happiness. Access to the economy and its products links homo oeconomicus with homo laborans, both chained to their own infinite material aspirations, the last human beings, the happy slaves "replete with the goods that [they] produce and consume without any other ideal than ensuring [their] own comfort and tranquillity" [18, p. 17]. With Adam Smith, therefore, necessity not freedom came to connote human history, as development was inscribed in the biological make up of humans. Whether such bio- logical necessity generates waste and devastation did not concern the founding fathers of economics as a science, because the spontaneous dynamic of growth was deemed capable of self-regulation. Human waste, in the form of labour cyclically expelled from the productive process, could sooner or later be absorbed into other, innovative, economic initiatives, while the harm caused to the environment will be mended by the very technology producing it [5]. We have no alternative, Smith remarked, to accepting the distributional inequities and moral violence that accompany private property relations, as these are the only means for securing our survival. On the other hand, this also means that selfishness should be the pivotal variable orienting our action, irrespective of how destructive this might be. Surely, there is a Christian-Hebraic stance in this suggestion, whereby a superior entity will arrange things so that every egoistic conduct will find its synthesis in a higher, inscrutable, harmony. This is a hubristic theory positing that we resemble the God who made us, and that we no longer need his judgement on our exploits. In sum, we are depicted as animals, full of instincts, innate desires and egoism, but 
at the same time as gods who turn their animal nature into universal harmony. This reveals a further contradicttion: despite the adherence to the doctrine of laissez-faire in theory, Adam Smith maintains a strong interest in promoting policies that further accumulation and favour enterprise, whether both generate harm or not.

Locke, Quesnay and Smith converge, in different fashions, into the practical philosophy or ideology of neoliberalism discussed above.

\section{Valueless Lives}

The harm caused by economic initiative, as externality, includes climate change, disposal of toxic waste, de-forestation, pollution of sea, air and land, gigantic disparities in income, transference of toxicity to poor regions and countries, impoverishment of vulnerable populations and destruction of communities [19]. These "ecocidal" tendencies [20] implicit in unfettered development are masked in a process whereby the specific victims of development itself disappear. Ideological strategies preside over this disappearance, among which a hierarchical positioning of populations and individuals is of crucial importance. Ontological priorities are established so that some lives are deemed less valuable than others: in fact, some lives are never lived nor lost in the full sense. There are lives worth living and lives worth destroying, the former being valuable and grievable, the latter devalued and ungrievable [21]. Utilitarian reasoning does not object to such distinction, as the suffering of some does not diminish the total happiness generated by the economy. This distinction, in other words, implies the neglect of individual wellbeing and happiness, while the ranking of social goodness and the selection of what is to be chosen is done simply on the basis of the sum total of individual welfares [22].

The utilitarian calculus based on happiness or desire-fulfilment can be deeply unfair to those who are persistently deprived since our mental make-up and desires tend to adjust to circumstances, particularly to make life bearable in adverse situations. It is through "coming to terms" with one's hopeless predicament that life is made somewhat bearable by the traditional underdogs, such as oppressed minorities in intolerant communities, sweated workers in exploitative industrial arrangements, precarious share-croppers living in a world of uncertainty, or subdued housewives in deeply sexist cultures [22, p. 282].

This "coming to terms" includes the acceptance of differentiated distribution of vulnerability and precariousness that the economy itself promotes.

According to another ideological strategy, development has to be seen as war, which requires sacrifice and, at time, heroes or martyrs. It would not be surprising, for instance, to hear such justification being mobilised by car manufacturers, who might claim that the victims of road accidents are no less than martyrs of the process of technological and economic advancement. Critical social scientists may argue, in this respect, that the translation of victims into martyrs requires the use of a high degree of hypocrisy [23], which is only acceptable in the name of sovereignty, and in our case, more specifically, in the name of economic development. However, a distinction may help clarify this critical argument.

In "The Fable of the Bees", Mandeville [24] distinguishes between malicious and fashionable hypocrites. The former are said to pretend blind faith in a creed, but know that their faith is false. The latter are forced to display their beliefs and show devotion lest they are excluded from the related social benefits that belief will bring. Using Mandeville's definitions, we can suggest that high-rank economic actors are malicious hypocrites, in that their belief in infinite development is unshaken by its visibly destructive consequences. By contrast, some underprivileged actors may be described as fashionable hypocrites, in that their faith in economic growth derives from the conviction that what they get out of it is better than nothing. As Sen [22] suggests, the hopelessly deprived may lack the will or even the desire to radically change their social conditions. An easy option for them is to limit their expectations to the minimum they are likely to achieve. Their desires, in other words, become adaptive and realistic, an adaptation to reality that at times includes the acceptance of potential death.

Can the situation be reversed? Can economic development turn its threats into opportunities? In conclusion of this paper the opinion of some who believe so is rapidly sketched.

\section{Human Development or De-Growth?}

When addressing the problems experienced by developing countries, many politicians, economists, policy-makers, and bureaucrats keep asserting that social conditions improve when, and only when, Gross Domestic Product (GDP) per capita increases. League tables are conesquently drawn where countries scoring very high in terms of GDP display enormous degrees of inequality, namely countries in which a large proportion of people do not enjoy the benefits of overall economic growth. For example, South Africa under apartheid, with its immense inequalities, used to occupy the top positions among developing countries.

Because countries respond to public rankings that affect their international reputation, this crude approach encourages them to work for economic growth alone, without attending to the living standard of their poorer inhabitants, and without addressing issues such as health and education, which typically do not improve with economic growth [25, p. ix].

If the goal of economic growth is the delivery of an 
adequate quality of life to everyone, all countries are developing countries. This observation has led to a new perspective in the debate around the functions of economic initiative, a new paradigm centred on the notions of "Human Development" and later "Capability Approach". The former appears each year in the UN Development Reports since 1990 and is based on the belief that the real wealth of a nation is its people. In this view, the purpose of economic development should be "to create an enabling environment for people to enjoy long, healthy, and creative lives" [25]. This simple but powerful truth is too often forgotten in the pursuit of material and financial wealth, with the consequence that economic development becomes increasingly extraneous to people's most urgent problems. Even the benefits of wealth resulting from foreign investment, it is noted, go in the first instance to elites, so that increased GDP does not affect wealth distribution.

The benefits of this increased wealth do not reach the poor, unless those local elites are committed to policies of redistribution of wealth; and they particularly do not reach poor women, whose employment opportunities are so much worse than those of men. Nor, as research shows, does economic growth by itself deliver improvements in health and education, in the absence of direct state action [25].

The Capability Approach asks: what is each person able to do and to be? Taking, in a Kantian fashion, each person as an end, it evaluates less the total or average well-being of a nation than the opportunities available to each individual. A set of opportunities to choose and to act constitute what Sen [26] calls "substantial freedoms", which refer to abilities and capabilities of functioning. These abilities do not only reside within individuals, but are also provided by the political, social and economic environment. They offer the possibility to choose and lead a life that is worthy of the human dignity. Economic development, in this perspective, should place all citizens above a specified threshold of capability, an achievement that is only possible if state action interferes with development itself.

In a more radical elaboration, economic growth is equated to a religion against which an atheist fight should be constantly fought [27]. Infinite growth is incompatible with a finite planet. Only a tenacious and irrational faith in "progress" can explain why economists and politicians continue to deny this reality. The provocative term "de-growth" is utilised to call for the abandonment of such faith and, as I have attempted to do in this paper, to contest economic thought itself and its supposed scientific status. As the great economist Schumpeter [28] warned: "the very ideas of economic thought are quenched in smoke, and few people, and least of all we economists ourselves, are prone to offer us congratulations on our intellectual achievements”.

\section{REFERENCES}

[1] M. Terni, "La Mano Invisibile Della Politica: Pace e Guerra Tra Stato e Mercato,” Garzanti, Milan, 2011.

[2] L. Gallino, "Finanzcapitalismo: La Civiltà Del Denaro in Crisi,” Einaudi, Turin, 2011.

[3] M. Douglas, "Risk and Blame: Essays in Cultural Theory,” Routledge, London, 1992. doi:10.4324/9780203430866

[4] N. Luhman, "Sociologia Del Rischio,” Bruno Mondadori, Milan, 1996.

[5] V. Ruggiero, "Invisible and Dingy Cities, in Movements in the City,” Prentice Hall, New York, 2001.

[6] J. Scorse, "What Environmentalists Need to Know about Economics,” Palgrave Macmillan, New York, 2010. doi:10.1057/9780230114043

[7] V. Ruggiero and N. South, "Green Criminology and Dirty Collar Crime,” Critical Criminology, Vol. 18, No. 4, 2010, pp. 251-262. doi:10.1007/s10612-010-9122-8

[8] M. J. Lynch, R. G. Burns and P. B. Stretesky, "Global Warming and State-Corporate Crime: The Politicalization of Global Warming under the Bush Administration," Crime, Law and Social Change, Vol. 54, No. 3-4, 2010, pp. 213-239. doi:10.1007/s10611-010-9245-6

[9] M. Weber, "Economy and Society: An Outline of Interpretive Sociology: Volume 1,” University of California Press, Berkeley, 1978.

[10] C. Tittle, “Control Balance,” Westview, Boulder, 1995.

[11] J. Waldron, “How Judges Should Judge,” Belknap Press/ Harvard University Press, Cambridge, 2006, pp. 54-59.

[12] J. Derrida, "Force de loi. Le 'Fondement Mystique de L'autorité',” Galilée, Paris, 1994.

[13] V. Ruggiero, "On Liberty and Crime: Adam Smith and John Stuart Mill,” Crime, Law and Social Change, Vol. 51, No. 3-4, 2009, pp. 435-450. doi:10.1007/s10611-008-9164-y

[14] A. Brisman, “The Indiscriminate Criminalisation of Environmentally Beneficial Activities,” In: R. White, Ed., Global Environmental Harm: Criminological Perspectives, Willan, Cullompton, 2010, pp. 89-102.

[15] J. Locke, “Two Treatises on Civil Government,” J. M. Dent \& Sons, London, 1962.

[16] F. Quesnay, “Tableau Economique,” Macmillan, London, 1972.

[17] A. Smith, "An Inquiry into the Nature and Causes of the Wealth of Nations," Clarendon Press, Oxford, 1976 (1776).

[18] M. Hénaff, “The Price of Truth: Gift, Money and Philosophy,” Stanford University Press, Stanford, 2010.

[19] R. White, Ed., "Global Environmental Harm: Criminological Perspectives,” Willan, Cullompton, 2010.

[20] N. South, “The Ecocidal Tendencies of late Modernity: Trans-National Crime, Social Exclusion, Victims and Rights,” In: R. White, Ed., Global Environmental Harm: 
Criminological Perspectives, Willan, Cullompton, 2010, pp. 143-158.

[21] J. Butler, “Frames of War: When Is Life Grievable?” Verso, London, 2010.

[22] A. Sen, “The Idea of Justice,” Belknap Press, Cambridge, 2009.

[23] D. Runciman, "Political Hypocrisy: The Mask of Power, from Hobbes to Orwell and Beyond,” Princeton University Press, Princeton, 2008.

[24] B. de Mandeville, “The Fable of the Bees,” Pelican, Har- mondsworth, 1970.

[25] M. C. Nussbaum, “Creating Capabilities: The Human Development Approach,” Harvard University Press, Cambridge, 2011. doi:10.4159/harvard.9780674061200

[26] A. Sen, "Development as Freedom,” Oxford University Press, Oxford, 1999.

[27] S. Latouche, “L’Invenzione Dell’Economia,” Bollati Boringhieri, Turin, 2010.

[28] J. A. Schumpeter, "History of Economic Analysis,” George Allen \& Unwin, London, 1954. 